\title{
Print is Dead
}




\section{Print is Dead Books in Our Digital Age}

Jeff Gomez

palgrave macmillan 


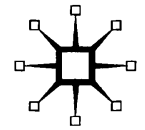

PRINT IS DEAD

Copyright (c) Jeff Gomez, 2008.

All rights reserved.

First published in hardcover in 2008 by PALGRAVE MACMILLAN $\otimes$ in the US a division of St. Martin's Press LLC, 175 Fifth Avenue, New York, NY 10010.

Where this book is distributed in the UK, Europe and the rest of the world, this is by Palgrave Macmillan, a division of Macmillan Publishers Limited, registered in England, company number 785998, of Houndmills, Basingstoke, Hampshire RG21 6XS.

Palgrave Macmillan is the global academic imprint of the above companies and has companies and representatives throughout the world.

Palgrave ${ }^{\circledR}$ and Macmillan ${ }^{\circledR}$ are registered trademarks in the United States, the United Kingdom, Europe and other countries.

ISBN 978-0-230-61446-8 ISBN 978-1-4299-5477-8 (eBook)

DOI 10.1007/978-1-4299-5477-8

A catalog record for this book is available from the Library of Congress.

A catalogue record for this book is available from the British Library.

First PALGRAVE MACMILLAN paperback edition: June 2009 


\section{contents}

introduction 1

stop the presses

1. byte flight $\mathbf{1 1}$

2. us and them 31

3. newspapers are no longer news 49

totally wired

4. generation download 67

5. generation upload $\mathbf{8 1}$

6. on demand everything 101

7. ebooks and the revolution that didn't happen $\mathbf{1 1 5}$

saying goodbye to the book

8. writers in a digital future $\mathbf{1 3 5}$

9. readers in a digital future $\mathbf{1 5 6}$

10. will books disappear? 175 
afterword 194

notes 204

acknowledgements 214

index 215 
For my loving wife, Colclough, who heard most of these ideas as soon as they popped into my head... and never once told me to shut up 
One of the questions that haunts me - it's a question for philosophers and brain science - is, if you've forgotten a book, is that the same as never having read it?

Tom Stoppard 